\title{
44607 - HEPARIN INFLUENCES S100B PROTEIN LEVELS IN BLOOD DURING CARDIAC SURGERY
}

\author{
C David Mazer, Department of Anesthesia, University of Toronto, Toronto, ON, Canada; \\ Sergey Novoshinov, Department of Anesthesia, University of Toronto; \\ Jim Tsoporis, Division of Cardiology, University of Toronto; \\ S Izhar, Division of Cardiology, University of Toronto; \\ C Tousignant, Department of Anesthesia, University of Toronto; \\ $D$ Latter, Division of Cardiovascular Surgery, University of Toronto; \\ GMT Hare, Department of Anesthesia, University of Toronto; \\ T Parker, Division of Cardiology, University of Toronto;
}

INTRODUCITON: S100B is an intracellular regulatory protein which is released following cardiopulmonary bypass (CPB) and thought to be related to neurological injury. Recently, S100B has been shown as key modulator of cardiac injury. Considering the increasing potential application of S100B measurment on clinical investigation, accurate evaluation of conditions that affect its measurment in blood is extremely important.The purpose of this study was to evaluate the potential influence of heparin on the measured level of S100B in blood of the patients undergoing cardiac surgery.

METHODS: With Research Ethic Board approval and informed consent, thirteen patients undergoing elective coronary artery bypass grafting (CABG) were recruited for the study. S100B levels were measured in arterial blood after induction of general anesthesia in three blood samples taken from each patient. Two samples were obtained at the same time prior to systemic heparinization: One sample had no heparin whereas heparin $5 \mathrm{U} / \mathrm{ml}$ was added to the other sample. The third sample was taken after intravenous heparin administration $(300 \mathrm{U} / \mathrm{kg})$ before initiation of cardio-pulmonary bypass. The time interval between the samples was less than 30 minutes. Serum from the non-heparinized samples or plasma from the heparinized samples were obtained following centrifugation of blood at $4000 \mathrm{~g}$ for 5 minutes. Serum and plasma samples were then frozen at $-70 \mathrm{C}$ until assayed. S100B levels were measured using a quantitative enzyme immunoassay (ELISA). Data (mean $\pm \mathrm{SD}$ ) was analyzed using ANOVA and linear regression.

RESULTS: The addition of exogenous heparin to blood samples $(5 \mathrm{U} / \mathrm{ml})$ resulted in a significant increase in the plasma levels of S100B when compared with non-heparinized serum samples $(0.130 \pm 0.027$ vs. $0.109 \pm 0.025 \mathrm{ng} / \mathrm{ml}$, respectively; $\mathrm{p}<0.05)$. There was a linear correlation between serum (no heparin) and plasma S100B levels when exogenous heparin was added $\left(5 \mathrm{U} / \mathrm{ml}, \mathrm{r}^{2}=0.84\right)$. The highest $\mathrm{S} 100 \mathrm{~B}$ levels were seen after systemic heparinization (300 $\mathrm{U} / \mathrm{kg}, 0.162 \pm 0.032 \mathrm{ng} / \mathrm{ml})$. These values were poorly correlated with the plasma levels before heparin administration $\left(\mathrm{r}^{2}=0.03\right)$.

DISCUSSION: This study demonstrates that adding heparin to the blood significantly increased the measured S100B levels in patients undergoing CABG surgery. After systemic heparinization, plasma S100B levels increased to a greater degree and no longer correlated with serum levels 
measured just prior to heparinization. These findings should be taken into consideration in clinical studies where the quantification of S100B is performed after systemic heparinization. 